\title{
The effects of bretylium on $\mathrm{C}$ fibre excitation \\ and noradrenaline release by acetylcholine and electrical stimulation
}

\author{
M. J. DAVEY, M. L. HAYDEN AND P. C. SCHOLFIELD
}

Therapeutics Research Division, Pfizer Limited, Sandwich, Kent

1. The effects of bretylium on the excitation of postganglionic adrenergic $\mathbf{C}$ fibres by acetylcholine and the release of noradrenaline by acetylcholine and electrical stimulation of the splenic nerves have been studied using the in situ and cross perfused cat spleen.

2. Close arterial injections of acetylcholine (10-200 $\mu \mathrm{g})$ evoked a brisk asynchronous discharge in fine filaments of the splenic nerve which reduced the height of the orthodromic $\mathrm{C}$ fibre compound action potential.

3. Hexamethonium abolished both the excitation of $\mathbf{C}$ fibres and release of noradrenaline by acetylcholine, whereas the liberation of noradrenaline by electrical stimulation of the splenic nerves remained unchanged.

4. Bretylium $(0.5$ and $1.0 \mathrm{mg})$ given close arterially blocked the output of noradrenaline and contractions of the spleen that occurred in response to nerve stimulation $(30 \mathrm{c} / \mathrm{s})$ but had much less effect on the responses to acetylcholine.

5. Bretylium (2-4 mg) given close arterially blocked the output of noradrenaline and contractions of the spleen caused by both nerve stimulation $(30 \mathrm{c} / \mathrm{s})$ and acetylcholine.

6. The close arterial injection of $(+)$-amphetamine sulphate $(100 \mu \mathrm{g})$ after bretylium (2-4 mg) partially restored the output of noradrenaline and contractions of the spleen to both nerve stimulation and acetylcholine.

7. The difference in the sensitivity to blockade by bretylium of the effects of nerve stimulation and the sympathomimetic effects of acetylcholine did not exist if the more "physiological" frequency of stimulation of $10 \mathrm{c} / \mathrm{s}$ was employed.

8. The close arterial injection of acetylcholine $(100 \mu \mathrm{g})$ caused a mean average fibre discharge frequency of 5.4 spikes/sec.

9. Bretylium in amounts sufficient to completely block the sympathomimetic effects of acetylcholine did not alter the excitation of $\mathrm{C}$ fibres by acetylcholine.

10. The significance of these results is discussed both in relation to the mode of action of bretylium and to the use of these differential effects of bretylium as evidence for the "cholinergic link" hypothesis.

Farber (1936) first described the sympathomimetic effect of acetylcholine on the spleen which was reinvestigated by Daly \& Scott (1961) and Brandon \& Rand (1961). 
Brandon \& Rand (1961) used their results to support the idea of the existence of a "cholinergic link" in the adrenergic sympathetic postganglionic pathway. Ferry (1963) concluded, on the basis of his experimental results, that acetylcholine excited the sympathetic postganglionic nerves of the spleen somewhere near their endings. Blakeley, Brown \& Ferry (1963) found that the anticholinesterases eserine and neostigmine did not affect the liberation by the nerves of the sympathetic transmitter. Furthermore, hexamethonium had no effect on the output of noradrenaline produced by electrical stimulation of the splenic nerves, whereas the release of noradrenaline by arterial injection of acetylcholine was prevented by hexamethonium. This observation confirmed the original finding of Daly \& Scott (1961) on the spleen of the dog. Ferry (1963) and Blakeley, Brown \& Ferry (1963) concluded that their results suggested a different interpretation of some of the evidence advanced in support of a "cholinergic link" in the post-ganglionic adrenergic sympathetic pathway. More recently Hertting \& Widhalm (1965) and Fischer, Weise \& Kopin (1966) reported that bretylium blocked the liberation of ${ }^{3} \mathrm{H}$-noradrenaline produced by electrical stimulation of the splenic nerves at dose levels that did not alter the release of noradrenaline by acetylcholine in the Krebs perfused cat spleen.

Burn (1967) has used these findings with bretylium as evidence against the conclusions of Ferry (1963) although Hertting \& Widhalm (1965) concluded that, in spite of their findings with bretylium, it was unlikely that acetylcholine played a part as an intermediary transmitter in postganglionic adrenergic sympathetic nerves.

Experiments were therefore conducted to investigate the phenomenon of bretylium being more effective in preventing the release of noradrenaline by nerve stimulation than the release of noradrenaline by acetylcholine. A brief account of some of these experiments was presented to the British Pharmacological Society (Davey, Hayden \& Scholfield, 1968).

\section{Methods}

\section{In situ preparation of the cat spleen}

Anaesthesia was induced with halothane $(3 \% \mathrm{v} / \mathrm{v})$ in nitrous oxide and oxygen $(3: 1 \mathrm{v} / \mathrm{v})$ and was maintained by the intravenous injection of chloralose $(80 \mathrm{mg} / \mathrm{kg})$. The spleen, its nerve supply, arterial supply and venous drainage were prepared as described by Brown \& Gillespie (1957). The stomach was removed in all experiments to enable better access to the arterial supply to the spleen. Acetylcholine and bretylium were injected directly into the splenic artery via a retrograde cannula placed in the hepatic artery. The venous outflow was collected for $30 \mathrm{sec}$ after the injection of acetylcholine. Platinum wire electrodes were used both for recording the activity in fine filaments of splenic nerve and for stimulating the peripheral end of the divided splenic nerve proximal to the recording electrodes. The activity in the fine filaments of splenic nerves was amplified with an a.c. amplifier and displayed on a cathode-ray oscilloscope.

\section{Cross perfusion of the isolated cat spleen}

The method used for perfusion of the spleen was essentially that used by Abercrombie, Davis \& Dwyer (1962) and has been described by Davey, Farmer \& Reinert (1963). 
The sympathin content of the plasma was assayed against noradrenaline on the blood pressure of the pithed rat. In all experiments the cats received atropine sulphate $(0.5 \mathrm{mg} / \mathrm{kg})$ given intravenously and heparin was used as anticoagulant.

\section{Drugs}

The drugs used were (+)-amphetamine sulphate, atropine sulphate, bretylium tosylate, hexamethonium bromide and (-)-noradrenaline bitartrate. With the exception of (-)-noradrenaline, all dose levels refer to the various salts employed.

a

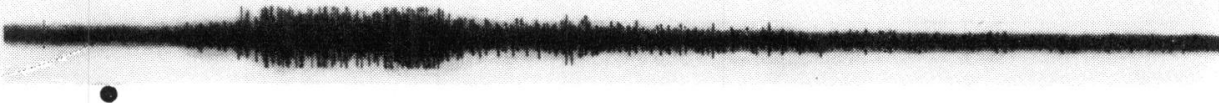

$$
\mathrm{ACh}
$$

b

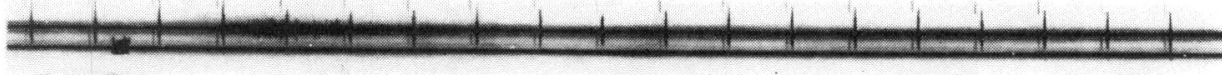

$\mathrm{ACh}$

c

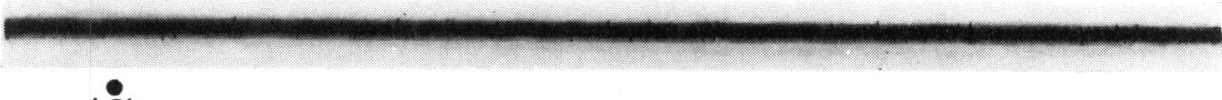

$$
\mathrm{ACh}
$$

d
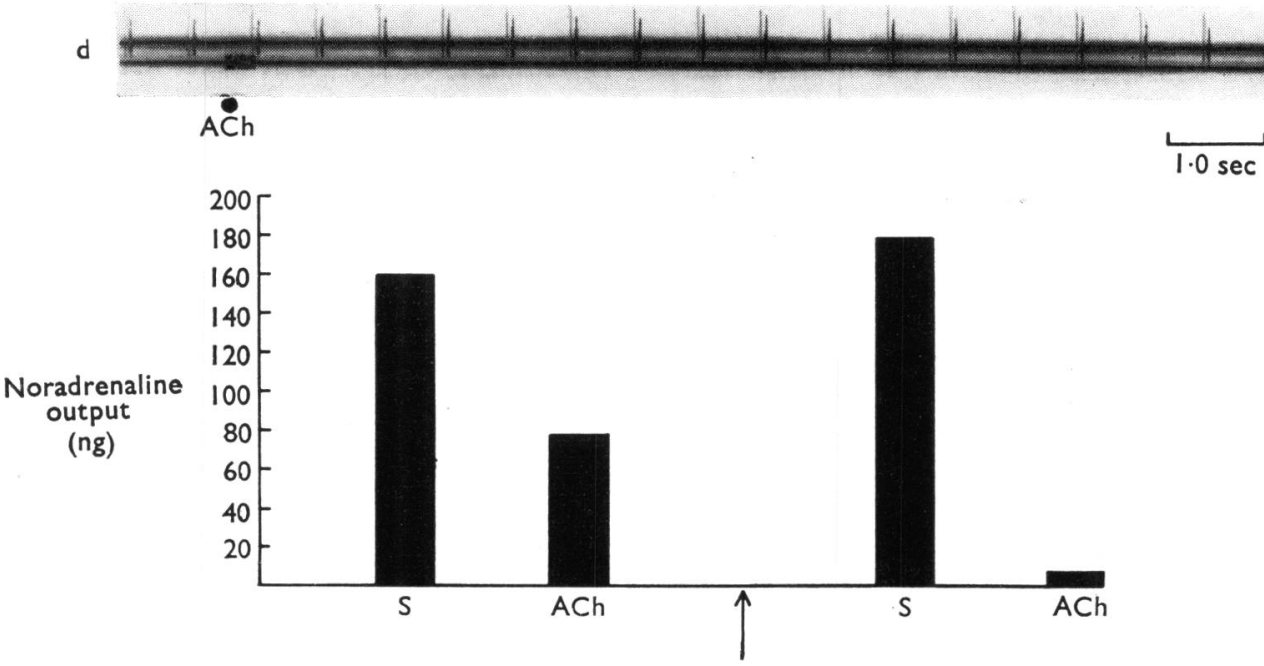

FIG. 1. Cat $3.5 \mathrm{~kg}$, male. Chloralose anaesthesia. a, b, c and d: Records from the peripheral end of a filament of the divided splenic nerve, the recording electrodes being placed distal to the stimulating electrodes. Records $a$ and $c$ are at four times the amplitude of $b$ and $d$, records $b$ and $d$ being at low amplitude to show the action potential propagated from the stimulating electrodes by regular supramaximal $(12 \mathrm{~V}, 0.5 \mathrm{msec})$ pulses at a frequency of $1.5 / \mathrm{sec}$. Histogram: Output of noradrenaline in venous outflow. ACh: Acetylcholine (100 $\mu \mathrm{g})$ injected directly into the arterial supply to the spleen via the hepatic artery. S: Splenic nerve stimulation with 200 supramaximal stimuli $(12 \mathrm{~V}, 0.5 \mathrm{msec}, 30 \mathrm{stimuli} / \mathrm{sec})$. Between $\mathrm{b}$ and $\mathrm{c}$ and at arrow, hexamethonium $(5 \mathrm{mg} / \mathrm{kg})$ given intravenously. 


\section{Results}

\section{Adrenergic $C$-fibre excitation and noradrenaline release by acetylcholine and nerve stimulation}

The close arterial injection of acetylcholine $(10-200 \mu \mathrm{g})$ evoked after a latent period of about $1 \mathrm{sec}$ a brisk asynchronous discharge in fine filaments of the splenic nerve lasting 10-20 sec in seventeen cats, confirming the original observation of Ferry (1963). This response could be repeated many times in each cat. These antidromic impulses evoked by acetylcholine reduced the height of the $\mathrm{C}$ fibre orthodromic compound action potential (conduction velocity approximately 0.5 $\mathrm{m} / \mathrm{sec}$ ) evoked by regular maximal stimulation of the splenic nerve at a frequency of 1.5 per sec proximal to the recording electrodes, thereby showing by the collision technique of Brown \& Pascoe (1952), as used by Ferry (1963), that acetylcholine was exciting $\mathrm{C}$ fibres (Fig. 1).

a

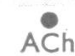

b
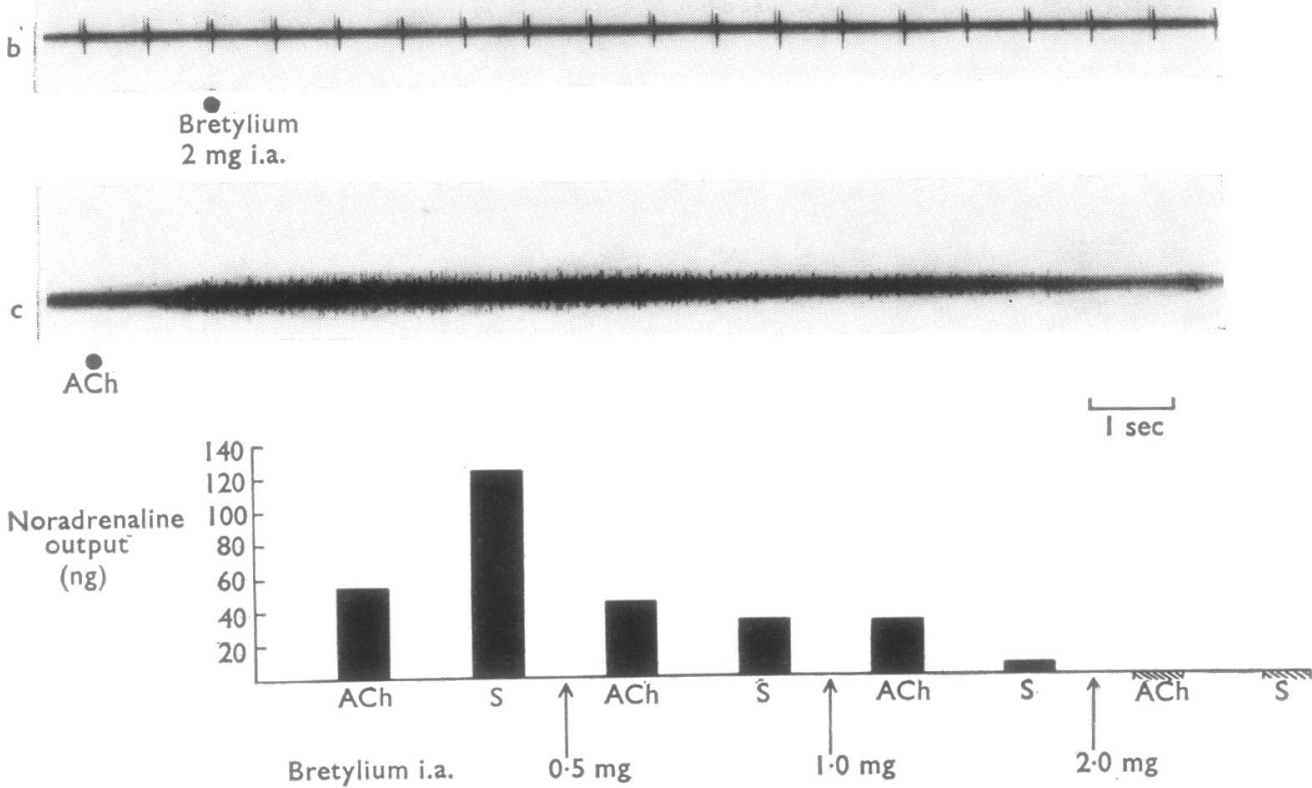

FIG. 2. Cat $2.5 \mathrm{~kg}$, female. Chloralose anaesthesia. a and c: Records of activity in a filament of divided splenic nerve produced by the close arterial injection of acetylcholine (100 $\mu \mathrm{g})$ before and after bretylium $(2 \mathrm{mg})$ was given close arterially, respectively. b: Action potential set up by regular supramaximal stimulation $(10 \mathrm{~V}, 0.5 \mathrm{msec}, 1.33 / \mathrm{sec})$ of the peripheral end of the divided splenic nerve proximal to the recording electrodes. Histogram: Output of noradrenaline in venous outflow. ACh: Close arterial injection of acetylcholine (100 $\mu \mathrm{g})$. S : Stimulation of the splenic nerves with a train of 200 supramaximal pulses $(10 \mathrm{~V}, 0.5 \mathrm{msec}$, $30 \mathrm{c} / \mathrm{s})$. At arrows, bretylium $(0.5,1.0$ and $2 \mathrm{mg})$ given close arterially. 
This excitation of $\mathrm{C}$ fibres by acetylcholine $(100 \mu \mathrm{g})$ was accompanied by the liberation of noradrenaline suggesting that the $\mathrm{C}$-fibres excited were in fact postganglionic adrenergic $C$ fibres. Hexamethonium $(5 \mathrm{mg} / \mathrm{kg})$ given intravenously abolished both the excitation of $\mathrm{C}$ fibres and the liberation of noradrenaline evoked by the close arterial injection of acetylcholine $(100 \mu \mathrm{g})$, whereas the release of noradrenaline by electrical stimulation of the splenic nerves at a frequency of $30 \mathrm{c} / \mathrm{s}$ and the $\mathrm{C}$ fibre spike set up by stimulation at a frequency of $1.5 \mathrm{c} / \mathrm{s}$ were not altered by hexamethonium in a total of three experiments (Fig. 1). These results are in complete agreement with the results of Blakeley, Brown \& Ferry (1963) and entirely compatible with the view that the sympathomimetic effects of acetylcholine are a consequence of acetylcholine exciting adrenergic $\mathrm{C}$ fibres somewhere near their endings.

\section{Bretylium on $C$ fibre excitation and noradrenaline release by acetylcholine and nerve stimulation}

Bretylium $(0.5$ and $1.0 \mathrm{mg})$ injected directly into the blood supply to the spleen was without effect on the amplitude of the $\mathrm{C}$ fibre spike and the close arterial injection of bretylium $(2.0 \mathrm{mg})$ caused only a slight transient reduction in the size of the C fibre spike produced by maximal stimulation of the splenic nerves proximal to the recording electrodes (Fig. 2). In agreement with Hertting \& Widhalm (1965) and Fischer et al. (1966), the close arterial injection of bretylium (0.5 and $1 \mathrm{mg})$ caused a much greater reduction in the output of noradrenaline that occurred in response to maximal stimulation of splenic nerves at a frequency of $30 \mathrm{c} / \mathrm{s}$ than to that produced by acetylcholine $(100 \mu \mathrm{g})$ given close arterially in five experiments. The results obtained in a typical experiment are shown in Fig. 2. Bretylium (2-4 $\mathrm{mg}$ ) given close arterially, however, completely abolished the liberation of noradrenaline by both acetylcholine and electrical stimulation of the splenic nerves (Fig. 2). The excitation of $\mathrm{C}$ fibres by acetylcholine was not reduced by bretylium even in amounts sufficient to abolish completely the release of noradrenaline by acetylcholine (Fig. 2). Thus the suggestion of Fischer et al. (1966) that amounts of bretylium which antagonize the sympathomimetic effect of acetylcholine do so by preventing the access of acetylcholine, is not correct.

\section{Bretylium on isolated cross-perfused cat spleen}

The isolated cross-perfused cat spleen, which permits the collection of a greater number of samples of the venous outflow than the in situ preparation of Brown \& Gillespie (1957), was used to study the effects of bretylium on the release of noradrenaline by acetylcholine and electrical stimulation of the splenic nerves. Bretylium (0.5, 1.0 and $2.0 \mathrm{mg}$ ) was injected directly into the arterial supply to the spleen in four preparations. The venous outflow during the following 2 min was collected separately and discarded in an attempt to prevent interference by the injected free bretylium in the assay of noradrenaline. The results obtained were similar in all four preparations. Bretylium at these dose levels caused no contraction of the capsular smooth muscle and no increase in the vasopressor activity of the venous blood from the spleen. At $5 \mathrm{~min}$ after the close arterial injection of bretylium $(0.5$ and $1.0 \mathrm{mg})$ the output of noradrenaline and contractions of the spleen produced by $30 \mathrm{c} / \mathrm{s}$ stimulation, were markedly diminished whereas the output of noradrenaline induced by the close arterial injection of acetylcholine $(100 \mu \mathrm{g})$ was. 
reduced to a lesser extent and the contractions of the spleen remained essentially unchanged (Fig. 3). Bretylium (2 mg) given close arterially, however, abolished the contractions of the spleen and liberation of noradrenaline by both $30 \mathrm{c} / \mathrm{s}$. stimulation and acetylcholine (Fig. 3). The contractions of the capsular smooth muscle evoked by close arterial injections of noradrenaline $(0.2 \mu \mathrm{g})$ were unchanged (Fig. 3). This block by bretylium of the liberation of noradrenaline by nerve stimulation and acetylcholine, once established, was extremely persistent and was still complete $180 \mathrm{~min}$ after the injection of bretylium, although the close arterial injection of (+)-amphetamine $(100 \mu \mathrm{g})$ (Davey \& Reinert, 1965) partially restored splenic contractions and noradrenaline liberation by both stimulation and acetylcholine (Fig. 3).

In all the preceding experiments comparison was made of the effects of bretylium on the overflow of the sympathetic transmitter produced by the close arterial injection of acetylcholine with that produced by exciting the splenic nerves with a train of 200 stimuli at a frequency of $30 \mathrm{c} / \mathrm{s}$. Fischer et al. (1966) stimulated the splenic nerves solely at a frequency of $30 \mathrm{c} / \mathrm{s}$ and unfortunately Hertting \& Widhalm (1965) in their short account did not state the frequency of stimulation that they employed.
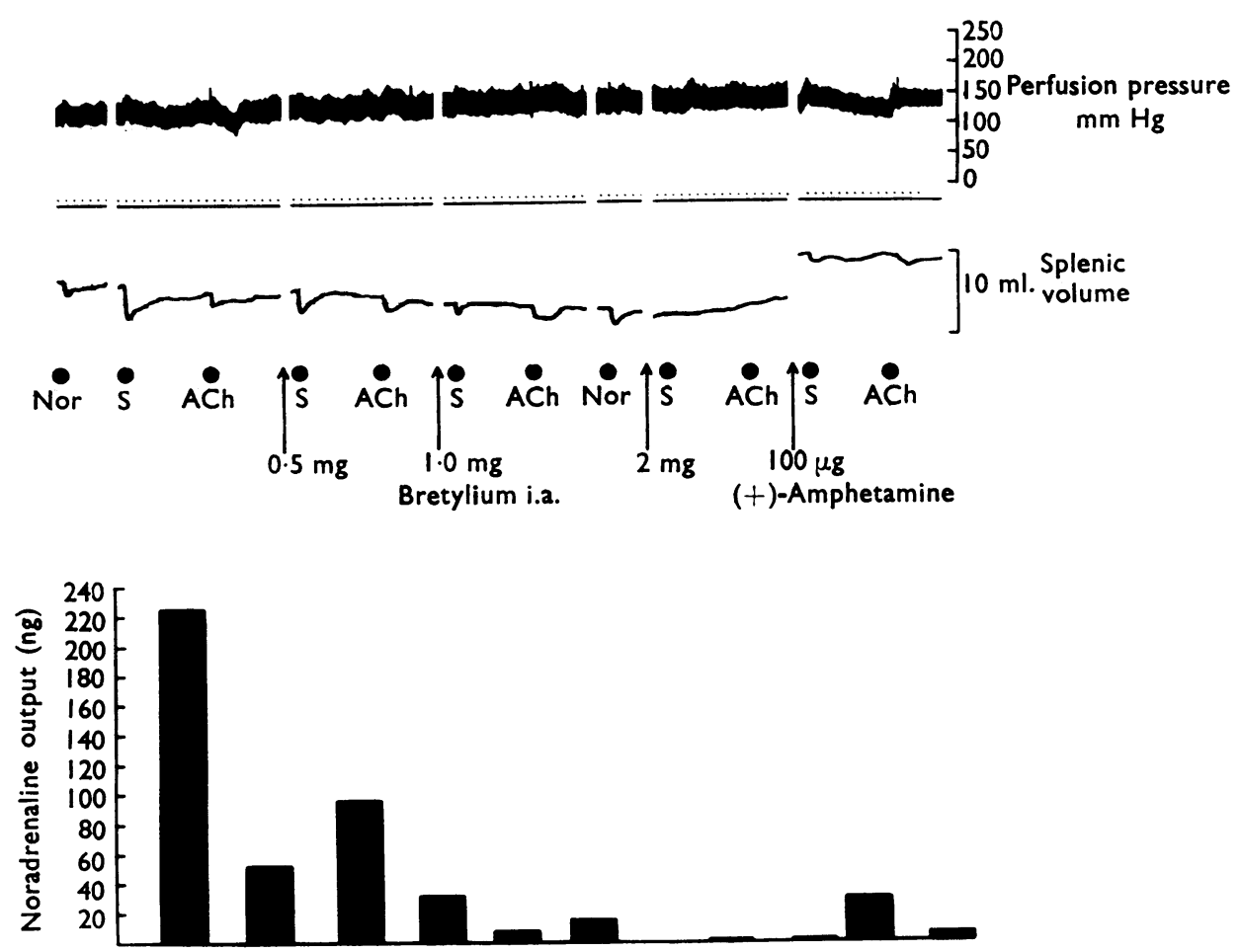

FIG. 3. Isolated perfused cat spleen. Spleen cat $2.8 \mathrm{~kg}$, male. Perfusion cat $3.2 \mathrm{~kg}$, male. Chloralose anaesthesia. Records of splenic perfusion pressure (top) and volume changes of the spleen, contractions downwards (bottom). Time scale, 1 min. Histogram: Output of noradrenaline in venous outflow. All drugs were injected directly into the arterial supply to the spleen. Nor: Noradrenaline $(0.2 \mu \mathrm{g}) ; \mathrm{ACh}$ : acetylcholine $(100 \mu \mathrm{g})$. At first three arrows bretylium $(0.5,1.0$ and $2 \mathrm{mg})$ and at last arrow $(+)$-amphetamine $(100 \mu \mathrm{g})$. S: Splenic nerve stimulation with 200 pulses $(20 \mathrm{~V}, 0.5 \mathrm{msec}, 30 \mathrm{stimuli} / \mathrm{sec})$. 
The overflow of noradrenaline into the blood stream produced by acetylcholine was always much less than that produced by $30 \mathrm{c} / \mathrm{s}$ stimulation of the splenic nerves. In three further experiments it was decided to excite the splenic nerves at the more "physiological" frequency of $10 \mathrm{c} / \mathrm{s}$, at which very little of the liberated transmitter overflows into the blood stream, in addition to $30 \mathrm{c} / \mathrm{s}$ stimulation.

Bretylium $(0.5 \mathrm{mg})$ given close arterially reduced both the contraction of the spleen and the output of noradrenaline produced by a train of 200 impulses at a frequency of $30 \mathrm{c} / \mathrm{s}$ but caused no reduction in either the splenic contracture or liberation of noradrenaline by 200 impulses at $10 \mathrm{c} / \mathrm{s}$ or the close arterial injection of acetylcholine $(100 \mu \mathrm{g})$ (Fig. 4). In all three preparations, bretylium $(0.5,1.0$ and $2.0 \mathrm{mg})$ had effects on both noradrenaline output and splenic contractions similar to either $10 \mathrm{c} / \mathrm{s}$ stimulation or acetylcholine $(100 \mu \mathrm{g})$ (Fig. 4). Thus the reported difference in the antagonism by bretylium of the effects of the close arterial injection of acetylcholine and nerve stimulation in the spleen appeared likely to be nothing more than a consequence of bretylium being more effective at blocking high frequencies of stimulation than low frequencies of stimulation. In this context it is relevant that Boura \& Green (1962) reported that bretylium depressed the slope of regression
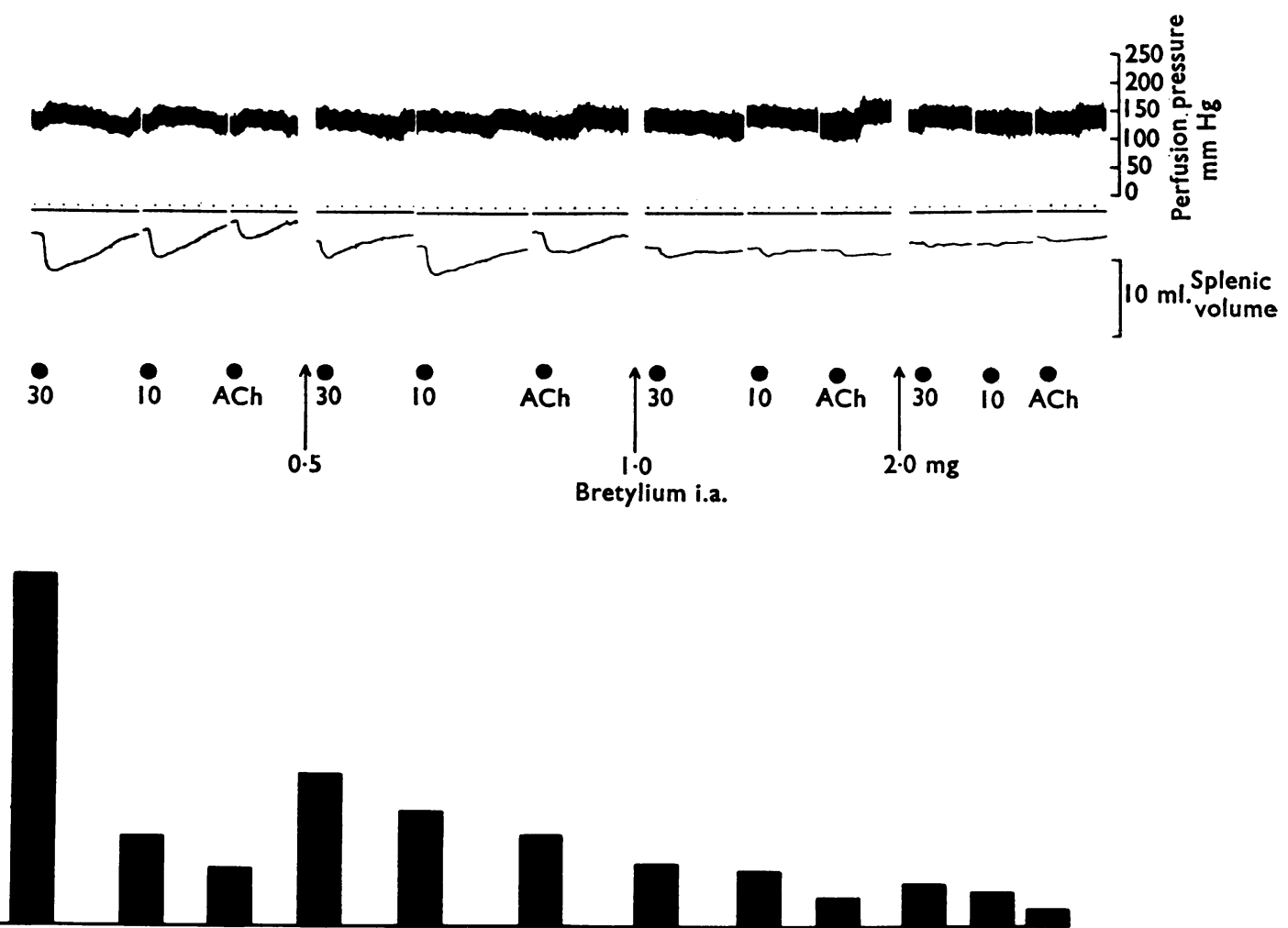

FIG. 4. Isolated perfused cat spleen. Spleen cat $2.8 \mathrm{~kg}$, female. Perfusion cat $3.4 \mathrm{~kg}$, female. Chloralose anaesthesia. Records of splenic perfusion pressure (top) and volume changes of the spleen, contractions downwards (bottom). Time scale, 1 min. Histogram: output of noradrenaline in venous outflow. ACh: Acetylcholine $(100 \mu \mathrm{g})$ injected directly into the arterial supply to the spleen. 30 and 10: Stimulation of splenic nerves with trains of 200 supramaximal pulses $(20 \mathrm{~V}), 0.5 \mathrm{msec}$ duration at frequencies of $30 \mathrm{stimuli} / \mathrm{sec}$ and $10 \mathrm{stimuli} /$ sec, respectively. At arrows, bretylium $(0.5,1.0$ and $2.0 \mathrm{mg})$ given close arterially. 
lines relating frequency of sympathetic nerve stimulation to magnitude of contractions of the cat nictitating membrane.

\section{Frequency of the discharge produced by acetylcholine}

It was clearly relevant to attempt to determine the frequency of the discharge elicited by acetylcholine. Ferry (1963) attempted to record the discharge of a single unit but found this difficult because even extremely fine filaments of the splenic nerves contained many active fibres and a multifibre response to acetylcholine was always obtained. An attempt was made to record the frequency of the discharge produced by close arterial injections of acetylcholine using very fine filaments of the peripheral end of the splenic nerves in four cats.

Figure 5 shows the spikes evoked by the close arterial injection of acetylcholine $(25,50,100$ and $200 \mu \mathrm{g})$ in one experiment. Unfortunately as the dose of acetylcholine was increased not only did the discharge frequency increase but also the number of fibres excited. The impulses produced by the close arterial injection of acetylcholine $(100 \mu \mathrm{g})$ on six extremely fine distal filaments of splenic nerve in three cats are shown in Fig. 6. By measuring the sizes of the action potentials to identify fibres, a total of seven fibres were unequivocally identifiable in the four experiments. It was found that acetylcholine $(100 \mu \mathrm{g})$ caused an irregular train of of peripheral end of the splenic nerve. Effects of close arterial injections of acetylcholine (a) $25 \mu \mathrm{g}$, (b) $50 \mu \mathrm{g}$, (c) $100 \mu \mathrm{g}$, (d) $200 \mu \mathrm{g}$. Time scales 10 and $100 \mathrm{msec}$. 
impulses at frequencies which varied from 1 to $50 / \mathrm{sec}$. The average frequency of the discharge varied between 2.9 and 8.5 spikes/ sec, however, with an overall mean of 5.4 spikes/sec for the seven fibres.

\section{Discussion}

Fischer et al. (1966) confirmed the original observation of Hertting \& Widhalm (1965) that bretylium blocked the liberation of ${ }^{3} \mathrm{H}$-noradrenaline by electrical stimulation of the splenic nerves at dose levels that did not alter the liberation of ${ }^{3} \mathrm{H}$-noradrenaline by acetylcholine in the Krebs perfused cat spleen. This led Fischer et al. (1966) to postulate first that bretylium blocked the nerve at a site proximal to the site of action of acetylcholine and second that the antagonism of the sympathomimetic effects of acetylcholine by higher concentrations of bretylium occurred because bretylium interfered with the entry of acetylcholine into the nerve endings. It occurred to us that this observation might be yet another example of the anomalous behaviour of spleens perfused with physiological salt solutions as opposed to blood. Using the blood perfused cat spleen and frequency of nerve
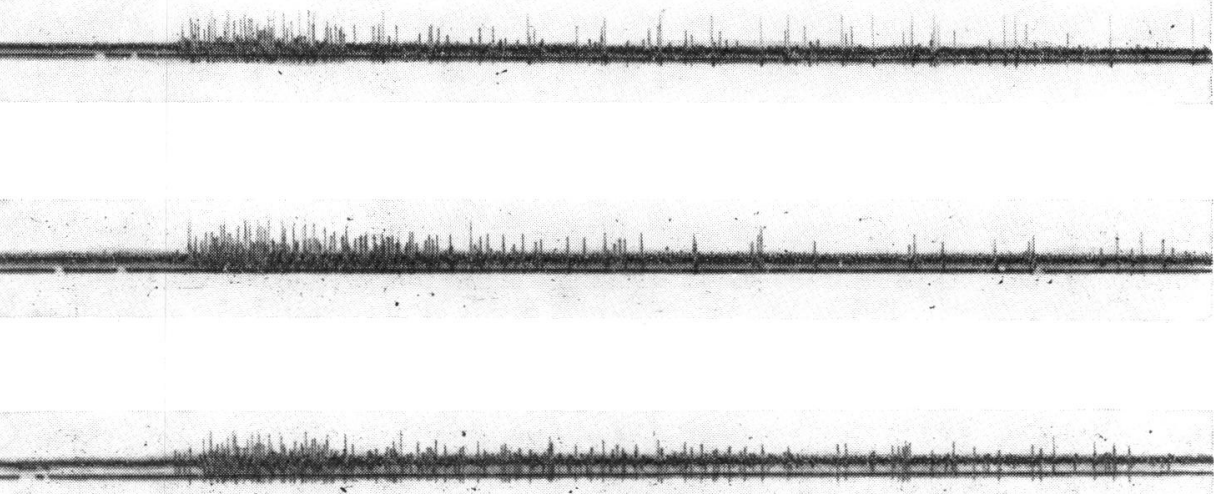

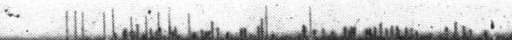

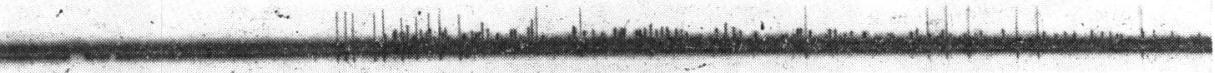

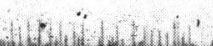

FIG. 6. Three cats, $2.7 \mathrm{~kg}$, male (records a and b), $2.4 \mathrm{~kg}$, female (records c and d) and 3.5 $\mathrm{kg}$, male (records e and f). Records of the effect of acetylcholine $(100 \mu \mathrm{g})$ given close arterially at signals on six fine filaments of the peripheral end of the splenic nerve. Time scales 10 and 100 msec. 
stimulation employed by Fischer et al. (1966), however, it was confirmed that bretylium caused greater reductions in the output of noradrenaline and contractions of the spleen caused by electrical stimulation of the splenic nerves than it did to those caused by close arterial injections of acetylcholine. The amount of noradrenaline that could be liberated into the venous outflow by acetylcholine was considerably less than that released by a train of impulses at $30 \mathrm{c} / \mathrm{s}$, so it was considered more pertinent to compare the antagonism by bretylium of the effects of acetylcholine with the antagonism of the effects of $10 \mathrm{c} / \mathrm{s}$ stimulation. When this was done it was found that the reported differences between the antagonism by bretylium of the effects of nerve stimulation and the close arterial injection of acetylcholine no longer existed, this finding being reminiscent of the observation of Boura \& Green (1962) that bretylium depressed the slope of regression lines relating frequency of stimulation to contraction of the cat nictitating membrane. An attempt was therefore made to determine the frequency of the discharge evoked by acetylcholine using extremely fine filaments of the splenic nerves and in fact a mean average discharge frequency of 5.4 spikes/sec was obtained. We are therefore led to conclude that the reported differences in the antagonism by bretylium of the effects of acetylcholine and nerve stimulation in the spleen are a consequence of bretylium being more effective at blocking high frequencies of stimulation than low frequencies of stimulation. The results certainly suggest a different interpretation from that of Fischer et al. (1966), namely that bretylium blocked the nerve at a site proximal to the site of action of acetylcholine. As a consequence it follows that the bretylium evidence cannot be used in support of the "cholinergic link" hypothesis, as Burn (1967) does in order to cast doubt as to the significance of the results of Ferry (1963). The second postulate of Fischer et al. (1966) that the antagonism of the sympathomimetic effects of acetylcholine by higher concentrations of bretylium was a result of bretylium interfering with the access of acetylcholine is clearly incorrect because bretylium in amounts that blocked the sympathomimetic effect of acetylcholine were without effect on the excitation of adrenergic $\mathrm{C}$ fibres by acetylcholine. Finally, this persistence of the acetylcholine evoked discharge, taken together with the fact that acetylcholine is almost certainly in this situation stimulating adrenergic C fibre endings, permits the observation of Exley (1960) that bretylium does not block axonal conduction to be extended to include even the terminal portion of the adrenergic neurone. That is to say, bretylium, which is frequently referred to as an adrenergic neurone blocking agent, certainly prevents "stimulus-transmitter release " coupling but in the conventional sense blocks no part of the postganglionic adrenergic neurone.

\section{REFERENCES}

Abercrombie, G. F., Davies, B. N. \& Dwyer, R. A. (1962). The isolated perfused cat's spleen; the measurement of volume changes and of the output of the sympathetic transmitter. $J$. Physiol., Lond., 161, 3P.

Blakeley, A. G. H., Brown, G. L. \& Ferry, C. B. (1963). Pharmacological experiments on the release of the sympathetic transmitter. J. Physiol., Lond., 167, 505-514.

Boura, A. L. A. \& Green, A. F. (1962). Comparison of bretylium and guanethidine tolerance, and effects on adrenergic nerve function and responses to sympathomimetic amines. $B r . J$. Pharmac. Chemother., 19, 13-41.

Brandon, K. W. \& RAND, M. J. (1961). Acetylcholine and the sympathetic innervation of the spleen. J. Physiol., Lond., 157, 18-32

Brown, G. L. \& Pascoe, J. E. (1952). Conduction through the inferior mesenteric ganglion of the rabbit. J. Phvsiol., Lond., 118, 113-123. 
Brown, G. L. \& Gillespie, J. S. (1957). The output of sympathetic transmitter from the spleen of the cat. J. Physiol., Lond., 138, 81-102.

BURN, J. H. (1967). Release of noradrenaline from the sympathetic postganglionic fibre. $B r . m e d$. J., 2, 197-201.

DALY, M. DE B. \& ScotT, M. J. (1961). The effects of acetylcholine on the volume and vascular resistance of the dog's spleen. J. Physiol., Lond., 156, 246-259.

DAVEY, M. J., FARMER, J. B. \& REINERT, H. (1963). The effects of nialamide on adrenergic functions. Br. J. Pharmac. Chemother., 20, 121-134.

Davey, M. J., Hayden, M. L. \& Scholfield, P. C. (1968). Bretylium on C fibre excitation and noradrenaline release by acetylcholine and electrical stimulation. Br. J. Pharmac. Chemother., 32, 423-424P.

Davey, M. J. \& Reinert, H. (1965). Pharmacology of the antihypertensive guanoxan. $B r . J$. Pharmac. Chemother., 24, 29-48.

EXLEY, K. A. (1960). The persistence of adrenergic nerve conduction after T.M. 10 or bretylium in the cat. Adrenergic Mechanisms, ed. Vane, J. R., Wolstenholme, G. E. W. \& O'Connor, M., pp. 158-161. London: Churchill.

FARBER, S. (1936). The action of acetylcholine on the volume of the spleen of the dog. Archs int. Pharmacodyn. Thér., 53, 367-376.

FERRY, C. B. (1963). The sympathomimetic effect of acetylcholine on the spleen of the cat. J. Physiol., Lond., 167, 487-504.

FisCHER, J. E., WeISE, V. K. \& Kopin, I. J. (1966). Interactions of bretylium and acetylcholine at sympathetic nerve endings. J. Pharmac. exp. Ther., 153, 523-529.

Hertting, G. \& Widhalm, S. (1965). Uber den mechanismus der Noradrenalin-Freisetzung aus sympathischen Nervendingungen. Arch. exp. Path. Pharmak., 250, 257-258. 